eager to join in any honest endeavour to frustrate their deceptions, and get at the truth; but not, I regret to say, in co-operation with your present associates." Muggeridge to Russell, 19 June 1964. Russell responded simply: "I have read with interest your letter, which I am sorry not to have answered earlier. I am glad to know your opinion on performing seals." Russell to Muggeridge, 23 July 1964.

${ }^{19}$ See, for instance, Staughton Lynd "The War Crimes Tribunal: A Dissent," Liberation 12 (December 1967/January 1968), 76-79. Lynd insisted that the War Crimes Tribunal, in order for it to have credibility, would have to investigate war crimes committed by both sides - even though he acknowledged the basic point that the Americans and their allies had committed the vast majority of offenses. "My position is that an action defined as a 'crime' remains criminal no matter who commits it."

20 "The Americans are so abominable," he told Merv Griffin on 28 June 1965. "To have an American autocracy throughout the world would be one of the most dreadful things that could happen. The only thing worse is a nuclear war." Transcript of interview in the Russell Archives.

${ }^{21}$ Russell to Khrushchev, 24 August 1964.

22 Russell to Khrushchev, I January 1961.

${ }^{23}$ Russell to Khrushchev, 26 February 1963. Emphasis added.

${ }^{24}$ George Orwell, The Lion and the Unicorn: Socialism and the English Genits (London: Sccker \& Warburg, 1941), 50 .

Matilde Zimmermann, Sandinista: Carlos Fonseca and the Nicaraguan Revolution (Durham, NC: Duke University Press, 2000).

"Son of a bitch! ... This is the worst decision I've ever made in my life," Omar Cabezas remembers thinking when he arrived at the heart of the mountains of Nicaragua, only to discover that the vaunted Sandinista guerrillas consisted of fifteen bedraggled kids lying around in hammocks.' Matilde Zimmermann's clear-eyed examination of that lonely period in the development of the Sandinista Front for National Liberation (FSLN) in the 1960s and early $1970 \mathrm{~s}$ makes a valuable contribution to understanding the history of the Nicaraguan revolution.

The only English-language biography of FSLN founder Carlos Fonseca, Sandinista, joins a select group of ground-breaking works that are essential reading on the intellectual and social context in which the Sandinista movement emerged. ${ }^{2}$ Zimmermann takes us behind the lenses of Fonseca's trademark thick eyeglasses, interviewing his contemporaries and mining a wealth of unpublished writings from Sandinista historical and military archives previously unavailable to outside researchers. By choosing to focus on the evolving ideology of this core protagonist who would not live to see the 1979 Sandinista 
triumph, she offers a complex interpretation of revolution as a contingent process, not an historical inevitability. This work joins ongoing theoretical debates over the relative priority of structure vs. agency in explaining revolution, emphasizing human agency by focusing on the role of ideology and leadership in the Nicaraguan revolution. ${ }^{3}$

Zimmermann departs from existing scholarship and conventional wisdom on the Sandinista revolution, on a number of significant points. One is her emphasis on how the Cuban revolution had a far more profound influence on Fonseca's thinking, and on the Sandinista movement, than the subsequent Sandinista narrative allows. The voluntarism of Che Guevara and the antiimperialist spunk of Fidel Castro captured the imagination of many a Third World would-be revolutionary. The same Fonseca who penned the embarrassingly uncritical essay "A Nicaraguan In Moscow" in 1958, by 1959 broke with the pro-Soviet Nicaraguan Socialist Party (PSN). Zimmermann argues that "the victory of the Cuban revolution convinced Carlos Fonseca that revolution was possible and that a new organization was needed to lead it" (56-7).

Closely related to this interpretation is Zimmermann's argument, based on meticulous examination of archival material, that Fonseca's "discovery" of Nicaraguan nationalist folk hero Augusto César Sandino came much later than others have assumed. This reinforces the point that the Cuban revolution of 1959 played a key role in transforming Fonseca, from an academic Marxist to a revolutionary practitioner rooted in the specific Nicaraguan experience. It was only then that Fonseca set about unearthing the history of Sandino's struggle of the 1920s and 1930s, which he presented accurately if selectively as a rallying symbol for the revolution (146-7). Zimmermann thus demystifies the process by which Sandino was chosen as a symbol for the Nicaraguan revolution. She also deflates the story that the FSLN was founded at a formal meeting on a specific date, suggesting instead a less epic and more unevenly unfolding process of foundation (73-7).

Several other reinterpretations of the historical record here emphasize the roots of the original revolution in Nicaragua's popular classes. This is an important contribution to the ongoing debates about whose revolution it was after 1979 , and what was left of the revolutionary project after the Sandinistas lost state power in 1990. ${ }^{4}$ Zimmermann suggests the Somoza regime had more strength and stability in the 1960 s and early 1970s than many latter-day accounts suggest, the FSLN was weaker, and the revolutionary momentum was driven from the grassroots. Many histories focus on the 1972 Managua earthquake, Somoza's graft in the post-earthquake reconstruction, and the consequent intra-elite divisions as a main turning point. Zimmermann argues however that the 1974 Sandinista raid on the Chema Castillo house, and the resulting widening wave of regime repression, had more significance in generating 
the broad popular mobilization that would bring down the dictatorship. She suggests that the regime's aerial bombardment destroyed factories not because they were owned by anti-Somoza capitalists, but because they were located in poor neighborhoods that were the heart of the insurrection $(210,218)$. Indeed, as the cycle of uprising and repression accelerated and widened, the sandinismo of Carlos Fonseca B the focus of this book B was folded into a revolutionary admixture of multi-class composition and eclectic ideology.

Fonseca's 1976 death in combat allowed everyone to reinvent the ideological primogenitor after the Sandinista victory of 1979. Zimmermann, who worked in solidarity with the Sandinistas in the 1980s, does not shy away from pointed observation about the Sandinista leadership's revisionism. This included a 1978 rewrite that watered down the 1969 "Historic Program" written by Fonseca (207-8), foreshadowing a continual series of compromises intended to placate the national bourgeoisie and forestall U.S. hostility.

Since structural constraints are not a major focus in this book, it may overestimate the degree to which Fonseca could have kept the revolution truer to its radical origins had he lived. Yet the Fonseca-centric perspective here is by no means hagiographic. The very human Carlos Fonseca that emerges in this fascinating portrayal is struggling with his identity as the illegitimate child of a wealthy somocista father and a poor rural washerwoman. He is an intense intellectual, yet plain-spoken; an ascetic, with puritanical views on marriage but critical of machismo; with undeveloped proto-ideas and blind spots about race as well as gender; anguished and frustrated with the slow progress of revolution in his beloved Nicaragua, from which he spent many years exiled.

One intriguing but ultimately unresolved issue examined in this book is the FSLN's ideological split into three "tendencies" in the mid-1970s, about which surviving leaders remain close-mouthed (164-7). Zimmermann argues that Nicaragua's historical backwardness held one advantage for revolutionary organizing, in limiting the crystallization of dogmatic factions and parties that had stifled creative praxis in the left elsewhere in Latin America. ${ }^{5}$ The FSLN's internal split was probably unknown or confusing to the general population and even to most Sandinistas in the 1970s, but Zimmermann's account may understate the development of the sectarian left in Nicaragua. There is no mention of the Maoists, whose Frente Obrero labour wing and Popular Anti-Somocista Militias (MILPAS) gave the Sandinista government headaches after 1979, and whose intellectuals led the peasant-centered campesinista dissent on agrarian policy. Also unmentioned are the Communist Party of Nicaragua (PCdeN), a Stalinist offshoot of the PSN that organized textile and other industrial unions, and the Trotskyist influence in the urban-based Movimiento Pueblo Unido (212). 
These splinter groups were small individually, but so were the Sandinistas for most of the 1960s-70s. The kinds of debates that gave rise to the FSLN's division remained sealed within the nine-man National Directorate rather than open to grassroots participation, an example of the verticalist practices that ultimately contributed to the Sandinistas' downfall (224).

Sandinista emphasizes the positive influence of the Cuban revolution, which counterposed a Guevarist optimism about the radical potential of the masses against the stultifying ideology of the Moscow-line PSN (225). Yet the success of the Sandinista revolution also depended on learning from the mistakes of the Cuban model, including the shortcomings of foquismo which almost led to the extinction of the FSLN in its early guerrilla campaigns (98). The Sandinistas faced a different constellation of domestic and international elements in 1979 from what the Cubans faced in 1959.

It is hard to resist the temptation to speculate what might have become of the Sandinista revolution if a leader with the vision and intensity of Carlos Fonseca had lived on. This book is not primarily about what went wrong with the revolution, but it offers thought-provoking material for anyone interested in that question. Zimmermann's insightful analysis of the Sandinistas' early years makes a valuable contribution to scholarship on Nicaraguan history and comparative revolution.

\section{Richard Stahler-Sholk}

Eastern Michigan University

1 Omar Cabezas, Fire from the Mountain: The Making of a Sandinista (New York: Penguin Books/Plume, 1986), 17.

2 Outstanding social histories of pre-revolutionary Nicaragua include Jeffrey L. Gould, To Lead as Equals: Rural Protest and Political Consciousness in Chinandega, Nicaragua, 1912-1979 (Chapel Hill: University of North Carolina Press, 1990); and Knut Walter, The Regime of Anastasio Somoza Garcia and State Formation in Nicaragua, 1936-1956 (Chapel Hill: University of North Carolina Press, 1987). Key works on the intellectual history of the Sandinista movement include Steven Palmer, "A. Carlos Fonseca and the Construction of Sandinismo in Nicaragua," Latin American Research Review 23 (1988): 91-109; and Donald C. Hodges, Intellectual Foundations of the Nicaraguan Revolution (Austin: University of Texas Press, 1986).

${ }^{3}$ Varied positions on the structure vs. agency debate can be found in John Foran, ed., Theorizing Revolutions (New York: Routledge, 1997).

${ }^{4}$ See, for example, Carlos M. Vilas, The Sandinista Revolution: National Liberation and Social Transformation in Central America (N.Y.: Monthly Review, 1986); Gary Prevost and Harry E. Vanden, eds., The Undermining of the Sandinista Revolution (N.Y.: St. Martin's Press, 1997); and Thomas W. Walker ed., Nicaragua without Illusions: Regime Transition and Structural Adjustment in the 1990s (Wilmington, DE: Scholarly Resources, 1997). 
${ }^{5}$ See Sheldon B. Liss, Marxist Thought in Latin America (Berkeley: University of California Press, 1984); Barry Carr and Steve Ellner, eds., The Latin American Left: From the Fall of Allende to Perestroika (Boulder: Westview Press, 1993); or for a cynical view, Jorge G. Castañeda, Utopia Unarmed: The Latin American Left after the Cold War (N.Y.: Vintage Books, 1994).

Michael Phayer, The Catholic Church and the Holocaust, 1930-1965 (Bloomington: Indiana University Press, 2000).

Don't be fooled by what is absent from the prosaic title. With The Catholic Church and the Holocaust, 1930-1965, Michael Phayer has written the best Pius XII book to appear in the recently resurgent controversy. By virtue of its attention-grabbing title, John Cornwell's Hitler's Pope (1999) is the best known of the lot. ${ }^{1}$ But Phayer, rejecting Cornwell's thesis that anti-Semitism is the best explanation for Pius XII's behavior during the Holocaust, undertakes a less sensational and more professional assessment. ${ }^{2}$

One must understand Cornwell's conclusion as part of a personal, journalistic quest to make sense of the Church's wartime record. Cornwell started to write his book in order to refute a group of young Catholics critical of Pius XII, who, one evening, had argued with him that, "the Church had sided with all the worst right-wing elements in the history of the 20th century." To his "moral shock," however, Cornwell discovered that, with regard to anti-Semitism, Pius XII was, on balance, part of the problem rather than part of any cure, either spiritual or political. Thus bewildered, Cornwell then drew hasty conclusions about Pius XII's personal motives.

Rather than inviting the reader to pass judgment on the anti-Semitism of one important man, and thus run the risk of scapegoating, Phayer provides the reader with evidence leading to more productive conclusions. They are more productive in that they address the collective responsibility of an institution, which still lives, and not the guilt of one man, who is now dead. Consequently, Phayer's book is the best one-volume introduction to the Holocaust memory that the Church, as an institution, must cultivate, at least if it is to face the future honestly.

Instead of focusing his narrative on the personality of the wartime Pope, Phayer tackles the question of Catholic anti-Semitism in a measured historical context: before, during, and after the Holocaust. Only four out of eleven chapters analyze events during the Holocaust: three analyze before, and four after. With the sweep of this non-biographical scope, Phayer is able to assess Pius XII more soundly than Cornwell. Paradoxically, by not making Pius XII the pri- 